\title{
A REVIEW OF OXIDATIVE STRESS IN ACUTE KIDNEY INJURY: PROTECTIVE ROLE OF MEDICINAL PLANTS-DERIVED ANTIOXIDANTS
}

\author{
Sarawoot Palipoch \\ School of Medicine, Walailak University, Nakhon Si Thammarat, 80161, Thailand \\ *E-mail: spalipoch@,hotmail.com, sarawoot.pa@wu.ac.th
}

\begin{abstract}
Acute kidney injury (AKI) is the common clinical syndrome which is associated with increased morbidity and mortality. The severity extends from less to more advanced spectrums which link to biological, physical and chemical agents. Oxidative stress (OS)-related AKI has demonstrated the increasing of reactive oxygen species (ROS) and reactive nitrogen species (RNS) and the decreasing of endogenous antioxidants. Medicinal plants-derived antioxidants can be ameliorated oxidative stress-related AKI through reduction of lipid peroxidation (LPO) and enhancement of activities and levels of endogenous antioxidants. Therefore, medicinal plants are good sources of exogenous antioxidants which might be considered the important remedies to ameliorate pathological alterations in oxidative stress-related AKI.
\end{abstract}

Key words: Acute kidney injury; Medicinal plant; Oxidative stress

\section{Introduction}

Kidney functions are excretions of waste products and toxins from blood circulation (approximately $20-25 \%$ from cardiac output), preservative of bodily fluids and electrolytes homeostasis, and regulation of blood pressure and hormone secretions. Counteraction of toxic substances in bloodstream against vessels, glomeruli and tubules of kidneys results in disruptions of renal architectures and functions. Acute kidney injury (AKI) is the common clinical complication which is associated with increased morbidity and mortality, affecting about $1-7 \%$ of hospitalised patients and $1-25 \%$ of patients in the intensive care unit (ICU) (de Mendonça et al. 2000; Nash et al. 2002). In clinical, AKI is a rapid reduction in kidney function, causing failure to maintain fluid, electrolyte and acid-base homeostasis. The Risk, Injury, Failure, Loss, and Endstage Kidney (RIFLE) classification proposed by the Acute Dialysis Quality Initiative (ADQI) group divides AKI into five stages, as follows: (1) Risk; (2) Injury; (3) Failure; (4) Loss of function; and (5) End stage kidney disease (ESKD) (Van Biesen et al. 2006; Bellomo et al. 2007) (Table 1).

Table 1: The Risk, Injury, Failure, Loss, and End-stage Kidney (RIFLE) classification of acute kidney injury (Bellomo et al., 2007)

\begin{tabular}{lll}
\hline Stage & Glomerular filtration rate (GFR) criteria & Urine output (UO) criteria \\
\hline Risk & $\begin{array}{l}\text { Increased serum creatinine } 1.5 \text { times or GFR decrease }> \\
25 \%\end{array}$ & $<5 \mathrm{~mL} / \mathrm{kg} / \mathrm{h}$ for $6 \mathrm{~h}$ \\
Injury & $\begin{array}{l}\text { Increased serum creatinine } 2 \text { times or } \\
\text { GFR decrease }>50 \%\end{array}$ & $<5 \mathrm{~mL} / \mathrm{kg} / \mathrm{h}$ for $12 \mathrm{~h}$ \\
Failure & $\begin{array}{l}\text { Increased serum creatinine } 3 \text { times or } \\
\text { GFR decrease }>75 \% \text { or serum creatinine }>4 \mathrm{mg} / \mathrm{dL}\end{array}$ & $<3 \mathrm{~mL} / \mathrm{kg} / \mathrm{h}$ for $24 \mathrm{~h}$ or anuria for $12 \mathrm{~h}$ \\
Loss & Complete loss of kidney function $>4$ weeks \\
ESKD & End stage kidney disease $(>3$ months) \\
\hline
\end{tabular}

Recently, the Acute Kidney Injury Network (AKIN) developed a new system for staging AKI which stages 1, 2 and 3 were corresponded with the risk, injury and failure categories (Table 2). The severity extends from less to more advanced spectrums which link to biological, physical and chemical agents. Ischemia and sepsis are common causative factors of AKI (Mehta et al., 2004). Functional and structural alterations of renal microvasculature are important processes contributing to the pathophysiology of AKI. The persistent deficit in renal blood flow has been posited to be intrinsically linked to tubular injury, inflammation and vascular alterations (Sutton 2009). In sepsis, AKI is triggered by both ischemic and inflammatory components, leading to the loss of renal epithelial cells and tubular cell dysfunction. Oxidative stress (OS) is the most 


\section{http://dx.doi.org/10.4314/ajtcam.v10i4.15}

important factor that is associated with various pathologies during AKI. This review emphasises the activities of antioxidants from phytochemical constituents of medicinal plants to insult OS-associated pathologies in AKI.

Table 2: The Acute Kidney Injury Network (AKIN) classification of acute kidney injury (Mehta et al., 2007)

\begin{tabular}{lll}
\hline Stage & Kidney functions & Urine output \\
\hline 1 & $\begin{array}{l}\text { Increase in serum creatinine } \geq 0.3 \mathrm{mg} / \mathrm{dL} \text { or increase } \\
\text { To } \geq 150-199 \%(1.5-1.9 \text { folds) from baseline }\end{array}$ & $<0.5 \mathrm{~mL} / \mathrm{kg} / \mathrm{h}$ for $\geq 6 \mathrm{~h}$ \\
2 & Increase in serum creatinine to $200-299 \%(>2-2.9$ folds $)$ from baseline & $<0.5 \mathrm{~mL} / \mathrm{kg} / \mathrm{h}$ for $\geq 12 \mathrm{~h}$ \\
3 & $\begin{array}{l}\text { Increase in serum creatinine to } \geq 300 \%(\geq 3 \text { folds }) \text { from baseline or } \\
\text { serum creatinine } \geq 4 \mathrm{mg} / \mathrm{dL} \text { with an acute rise of at least } 0.5 \mathrm{mg} / \mathrm{dL} \text { or } \\
\text { initiation of renal replacement therapy }\end{array}$ & $\begin{array}{l}<0.3 \mathrm{~mL} / \mathrm{kg} / \mathrm{h} \geq 24 \mathrm{~h} \\
\text { or anuria } \geq 12 \mathrm{~h}\end{array}$ \\
& & \\
\hline
\end{tabular}

\section{Oxidative stress and antioxidant defence system}

OS is an imbalance among the rate of production and removal of oxidant and common causative factor of various diseases such as ischemia, atherosclerosis, neurodegenerative diseases and aging (Sorg 2004; Salmon et al., 2010). OSmediated molecules are ROS and RNS (Sorg 2004). ROS are several reactive molecules and free radicals derived from molecular oxygen as illustrated in Fig.1. The most important ROS are consisted of superoxide anion $\left(\mathrm{O}_{2}{ }^{-}\right)$, hydroxyl radical $(\mathrm{OH})$, hydrogen peroxide $(\mathrm{H} 2 \mathrm{O} 2)$; and hypochlorous acid $(\mathrm{HOCl})$. These species are involved in the regulation of fundamental cellular activities. At high concentration, ROS are the highly reactive molecules that are able to become toxic to macromolecules, including lipid, protein and DNA, and hence, cause disruption of the cellular structural integrity and capacity. ROS are produced in both endogenous and exogenous sources. Endogenous sources are consisted of mitochondrial electron transport chain, phagocytes (respiratory burst), oxidant enzyme (xanthine oxidase), and auto-oxidation reaction (Young \& Woodside 2001; Valko et al., 2007). Environmental agents include radiations, xenobiotics, chlorinated compounds, cigarettes and alcohols (Ziech et al., 2010). RNS are by-products of nitric oxide ( $\mathrm{NO}$ ), which plays a key role in maintaining various physiological functions but can also contribute to several pathological processes at high levels. RNS are comprised of nitrite $\left(\mathrm{NO}_{2}^{-}\right)$, nitrate $\left(\mathrm{NO}_{3}{ }^{-}\right)$and peroxynitrite $\left(\mathrm{ONOO}^{-}\right)$. To prevent ROS/RNS-caused cellular damage, the body has a defence system called antioxidant.

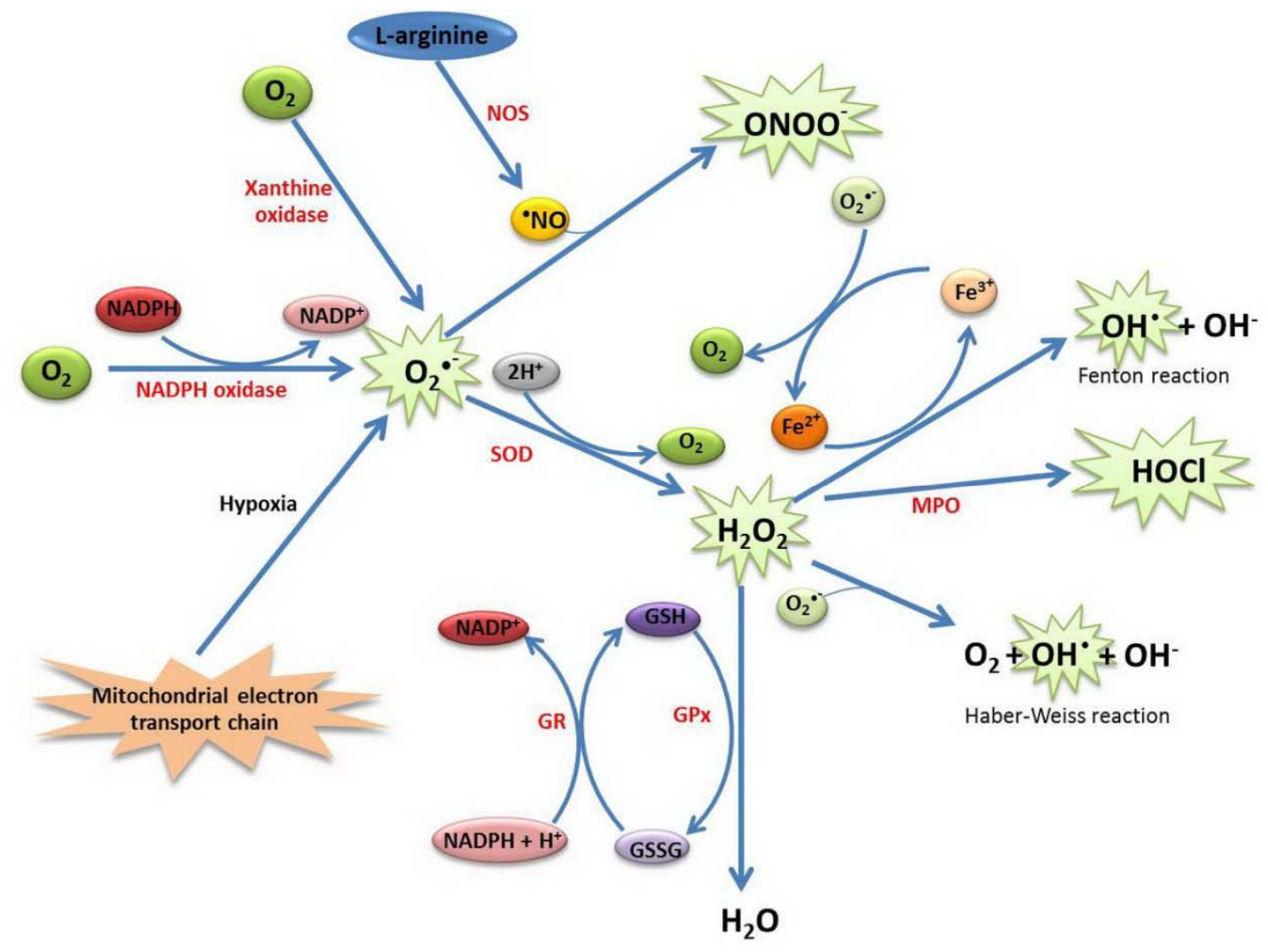




\section{http://dx.doi.org/10.4314/ajtcam.v10i4.15}

Figure 1: Generation of ROS and RNS (modified from Valko et al., 2007). Note: superoxide anions $\left(\mathrm{O}_{2}{ }^{\circ}\right)$; hydroxyl radical ( $\mathrm{OH})$; hydrogen peroxide ( $\mathrm{H} 2 \mathrm{O} 2)$; hypochlorous acid ( $\mathrm{HOCl})$; peroxynitrite $\left(\mathrm{ONOO}^{-}\right)$; nitric oxide ("NO); nitric oxide synthase (NOS); superoxide dismutase (SOD); myeloperoxidase (MPO); glutathione peroxidase (GPx); glutathione reductase (GR); reduced glutathione (GSH); oxidized glutathione (GSSG); nicotinamide adenine dinucleotide phosphate (NADPH); ferric $\left(\mathrm{Fe}^{3+}\right)$; and ferrous $\left(\mathrm{Fe}^{2+}\right)$

Antioxidant systems prevent uncontrolled formation of free radicals and activated oxygen species, or inhibit their reactions with biological structures (Riley 1994). Antioxidants are any substances which can inhibit the oxidation of oxidative substrates (Halliwell 1995). They have several molecules that play a role in antioxidant defence, including endogenous (internally synthesised) and exogenous (consumed) antioxidants. They can be divided into two types depending on mechanism of action, either chain breaking antioxidants or preventive antioxidants (Benzie \& Strain 1999). Preventive antioxidants reduce the rate of chain initiation by deactivating metals, quenching singlet oxygen and removing hydroperoxides, including transferrin, ferritin, ethylenediaminetetraacetic acid (EDTA), ceruloplasmin, catalase, SOD and GPx. Whereas, chain breaking antioxidants are the molecules that have the ability to receive or donate an electron from a radical with the formation of stable byproducts including $\alpha$-tocopherol, ascorbic acid, uric acid and $\beta$-carotene (Halliwell 1995; Young \& Woodside 2001).

\section{Medicinal plants-derived antioxidants}

Medicinal plants are used for the treatment of various diseases in several decades. They were shown to be good, effective, inexpensive, safe, and available. Current researches and financial supports have shown increased interest in their advantage. Currently, extraction and development of several drugs and chemotherapeutics from these plants have been widely observed. Medicinal plants have always been considered a healthy source for the prevention of various OS-related diseases (Sailaja \& Setty 2006; Olaleye \& Rocha 2008; Qin et al., 2009; Reddy et al., 2009; Marnewick et al., 2011; Sen et al., 2011; Keter \& Mutiso 2012). They compose a wide variety of phytochemical constituent molecules that have the antioxidant properties including carotenoids and phenolic compounds (Auddy et al., 2003; Bouayed et al., 2007; Huang et al., 2010; Awah et al., 2012). Carotenoids are categorised as tetraterponoids, which are divided into two major structural groups: (1) molecules containing oxygen, xanthophylls such as lutein and $\beta$-cryptoxanthin, and (2) un-oxygenated carotenes which include hydrocarbon carotenoids that are either cyclised such as $\alpha$-carotene and $\beta$-carotene or linear, like lycopene (Mein et al., 2011). They have demonstrated antioxidant activity such as chain breaking antioxidants (Bast et al., 1998; Palace et al., 1999). High carotenoid intakes have a significantly reduced risk of several chronic and degenerative diseases (Cooper et al., 1999; Rao \& Agarwal 2000; Rao \& Rao 2007). While, phenolic compounds are mainly consisted of flavonoids, tannin and phenolic acids usually found in medicinal plants and food products. Flavonoids constitute the largest group of plant phenolics, including anthocyanidin, anthochlors, auronus, flavonones, dihydroflavone, flavone, flavonols and isoflavonoid which also display a wide range of antioxidant properties (Reyes et al., 2005; Azevedo et al., 2010; Martins et al., 2011; Qin et al., 2011). Phenolic acids constitute also an important antioxidant of phenolic compounds which can be divided into two subgroups: hydroxybenzoic or hydroxycinnamic acids (Sroka \& Cisowski 2003; Cheng et al., 2007; Martins et al., 2011).

\section{Protective effect of medicinal plants-derived antioxidants in OS-related AKI}

Kidney damage in OS-related AKI was associated with increased ROS/RNS production, leading to oxidation of several macromolecules (e.g. protein, DNA and lipid). Production of lipid peroxidation (LPO) in OS-related AKI results in large production of secondary products such as malondialdehye (MDA) and 4-hydroxynonenal (Cristol et al., 1996). LPO refers to the oxidation of lipids particularly polyunsaturated fatty acids by mechanism of free radical chain reaction. Like ROS/RNS, resulting lipid peroxides are dangerous to cells due to its ability to sustain free radical cascades, eventually leading to increased membrane rigidity and abnormalities of endothelial function which may be involved in the pathophysiology of AKI (Pieper et al., 1997; Farooqui \& Horrocks 1998). Moreover, OS-related AKI was significantly reduced by endogenous antioxidants (Seok et al., 2007; Ghule et al., 2011). GR-deficient mice were used to demonstrate ROS-mediated renal proximal tubule injury (Rogers et al., 2006). Medicinal plants-derived antioxidants ameliorated kidney against OS during AKI as summarised in Table 3.

Medicinal plants-derived antioxidants can be protected against renal damage through reduced LPO and increased endogenous antioxidants. Increased activities and levels of endogenous antioxidants are the key factors to reduced OSinduced AKI. Endogenous antioxidants are mainly comprised of SOD, catalase, GPx, GR and GSH. SOD converts $\mathrm{O}_{2}{ }^{\circ}$ into $\mathrm{H}_{2} \mathrm{O}_{2}$ as shown in Fig. 1. There are 3 forms of SOD in mammalian tissues depending on a specific subcellular location and different tissue distribution including copper zinc-SOD (found in the cytoplasm and organelles), manganese-SOD (found in the mitochondria) and extracellular SOD (expressed on the cell surface) (Young \& Woodside 2001). Catalase is an endogenous antioxidant enzyme which protects body from OS by converting $\mathrm{H}_{2} \mathrm{O}_{2}$ into water and oxygen. It is highly abundant within peroxisomes, which also contain most of enzymes capable of generating $\mathrm{H}_{2} \mathrm{O}_{2}$. The amount of catalase in cytoplasm and other subcellular compartments remain unclear, because peroxisomes are easily ruptured during the manipulation of cells. The most activity is present in liver and the red blood cell (Young \& Woodside 2001). GPx is known as primary antioxidant in the body and is believed to synthesise mainly in kidney (Roxborough et al., 1999). The highest concentrations are found in the liver. The predominant subcellular distribution is found in cytosol and mitochondria, suggesting that GPX is the main scavenger of $\mathrm{H}_{2} \mathrm{O}_{2}$ in those compartments. GR is an important cellular enzyme which converts GSSG into GSH as illustrated in Figure 1.

Cells that are exposed to high levels of OS are needed for this reaction. Augusti et al., (2008) demonstrated the protective role of astaxanthin against mercury nephrotoxicity by reducing OS. A carotenoid, astaxanthin is able to prevent the 


\section{http://dx.doi.org/10.4314/ajtcam.v10i4.15}

increased LPO and protein oxidation and attenuate histopathological changes caused by mercuric chloride in kidney. In addition, it can protect the depression of SOD activity (Augusti et al., 2008). Khan et al., (2010) provide evidence that potassium dichromate administration caused nephrotoxicity in both proximal tubule and glomerulus through OS induction. Tocotrienol, a member of vitamin E family, supplementation exhibited the capacity to reduce proximal tubular injury and renal LPO, and increased GSH level and catalase activity. Moreover, it is able to improve the index of $\mathrm{NO}_{2}{ }^{-} / \mathrm{NO}_{3}{ }^{-}$generation.

Table 3: Mechanism of medicinal plants-derived antioxidants ameliorated kidney against oxidative stress during AKI

\begin{tabular}{|c|c|c|}
\hline Antioxidants & Mechanism to prevent oxidative stress-induced AKI & References \\
\hline Astaxanthin & $\begin{array}{l}\text { - Increased SOD activity } \\
\text { - Reduced protein and LPO }\end{array}$ & (Augusti et al., 2008) \\
\hline Tocotrienol & $\begin{array}{l}\text { - Increased GSH level, catalase activity in the renal cortex } \\
\text { - Increased urinary excretion of NO } \\
\text { - Reduced renal LPO }\end{array}$ & (Khan et al., 2010) \\
\hline Phenolics & $\begin{array}{l}\text { - Decreased renal xanthine oxidase activity and serum nitrate/ nitrite } \\
\text { - Increased the activities of SOD, catalase, glutathione-S-transferase and } \\
\text { glucose-6-phosphatase } \\
\text { - Reduction of renal LPO }\end{array}$ & (Ekor et al., 2010) \\
\hline Ligustrazine & $\begin{array}{l}\text { - Reduced MPO activity } \\
\text { - Increased SOD activity } \\
\text { - Reduced renal LPO }\end{array}$ & (Feng et al., 2011) \\
\hline Troxerutin & $\begin{array}{l}\text { - Increased SOD, CAT and GPx activity } \\
\text { - Reduced renal LPO }\end{array}$ & (Fan et al., 2009) \\
\hline
\end{tabular}

The investigation suggested that tocotrienol can be considered a natural antioxidant supplement protecting the kidney pathology induced by potassium dichromate (Khan et al., 2010). Ligustrazine is an alkaloid extracted from Ligusticum wallichii which exhibited the scaveging properties of ROS. Feng et al., (2011) demonstrated the ability of ligustrazine to protect kidneys from warm ischemia/reperfusion injuries by decreasing ROS generation, reducing MDA, a lipid peroxidation biomarker and elevating SOD activity (Feng et al., 2011). Fan et al., (2009) illustrate the effectively antioxidant activity of troxerutin to attenuate the renal injury induced by D-galactose in mice. Troxerutin, a rutoside derivative, is found abundant in tea, coffee, cereal grain and a variety of fruits and vegetables elicited the ability to elevate antioxidant enzyme activities, including $\mathrm{Cu} / \mathrm{Zn}$ SOD, GPx and catalase and to reduce MDA level (Fan et al., 2009). Recent studies by Palipoch et al., (2011) indicated that leaf extract of Thai herb, Thunbergia laurifolia, has the ability to reduce OS-associated kidney damage induced by lead (II) nitrate in fish. Supplementation of T. laurifolia leaf extracts is able to increase the activities of intrinsic antioxidant, including GSH, GPx, GR and catalase and able to deplete LPO, ultimately reducing kidney pathology. They suggested that constituents in leaf extract including chlorophyll derivatives, apigenin and caffeic acid may act as antioxidant (Palipoch et al., 2011a, b).

\section{Conclusion}

OS is one of the important factors contributing to AKI by increasing production of oxidants, particularly ROS and RNS and/or ineffective/insufficiency of endogenous antioxidant defence system. Medicinal plant-derived exogenous antioxidants are demonstrated to ameliorate AKI-induced OS by reduced LPO and enhanced oxidant scavenging ability of antioxidant defence system. We suggested that supplementation of antioxidant obtained from medicinal plants might be considered the important remedy to abrogate pathology of OS-related AKI.

\section{Acknowledgements}

The author deeply thanks Dr. Chuchard Punsawad, Dr. Phanit Koomhin, the Dean and all staff of School of Medicine, Walailak University, Thailand for their kind support and encouragement 
http://dx.doi.org/10.4314/ajtcam.v10i4.15

\section{References}

1. Auddy, B., Ferreira, M., Blasina, F., Lafon, L., Arredondo, F., Dajas, F., Tripathi, P.C., Seal, T. and Mukherjee, B. (2003). Screening of antioxidant activity of three Indian medicinal plants, traditionally used for the management of neurodegenerative diseases. J. Ethnopharmacol., 84: 131-138.

2. Augusti, P.R., Conterato, G.M., Somacal, S., Sobieski, R., Spohr, P.R., Torres, J.V., Charão, M.F., Moro, A.M., Rocha, M.P., Garcia, S.C. and Emanuelli, T. (2008). Effect of astaxanthin on kidney function impairment and oxidative stress induced by mercuric chloride in rats. Food Chem. Toxicol., 46: 212-219.

3. Awah, F.M., Uzoegwu, P.N., Ifeonu, P., Oyugi, J.O., Rutherford, J., Yao, X., Fehrmann, F., Fowke, K.R. and Eze, M.O. (2012). Free radical scavenging activity, phenolic contents and cytotoxicity of selected Nigerian medicinal plants. Food Chem., 131: 1279-1286.

4. Azevedo, J., Fernandes, I., Faria, A., Oliveira, J., Fernandes, A., Freitas, V.d. and Mateus, N. (2010). Antioxidant properties of anthocyanidins, anthocyanidin-3-glucosides and respective portisins. Food Chem., 119: 518-523.

5. Bast, A., Haenen, G.R., van den Berg, R. and van den Berg, H. (1998). Antioxidant effects of carotenoids. Int. J. Vitam. Nutr. Res., 68: 399-403.

6. Bellomo, R., Kellum, J.A. and Ronco, C. (2007). Defining and classifying acute renal failure: from advocacy to consensus and validation of the RIFLE criteria. Intensive Care Med., 33: 409-413.

7. Benzie, I.F. and Strain, J.J. (1999). Ferric reducing/antioxidant power assay: direct measure of total antioxidant activity of biological fluids and modified version for simultaneous measurement of total antioxidant power and ascorbic acid concentration. Methods Enzymol., 299: 15-27.

8. Bouayed, J., Piri, K., Rammal, H., Dicko, A., Desor, F., Younos, C. and Soulimani, R. (2007). Comparative evaluation of the antioxidant potential of some Iranian medicinal plants. Food Chem., 104: 364-368.

9. Cheng, J.C., Dai, F., Zhou, B., Yang, L. and Liu, Z.L. (2007). Antioxidant activity of hydroxycinnamic acid derivatives in human low density lipoprotein: Mechanism and structure-activity relationship. Food Chem., 104: 132-139.

10.Cooper, D.A., Eldridge, A.L. and Peters, J.C. (1999). Dietary carotenoids and certain cancers, heart disease, and agerelated macular degeneration: a review of recent research. Nutr. Rev., 57: 201-214.

11.Cristol, J.P., Thiemermann, C., Guerin, M.C., Torreilles, J. and de Paulet, A.C. (1996). L-Arginine infusion after ischaemia-reperfusion of rat kidney enhances lipid peroxidation. J. Lipid Mediat. Cell Signal., 13: 9-17.

12.de Mendonça, A., Vincent, J.L., Suter, P.M., Moreno, R., Dearden, N.M., Antonelli, M., Takala, J., Sprung, C. and Cantraine, F. (2000). Acute renal failure in the ICU: risk factors and outcome evaluated by the SOFA score. Intensive Care Med., 26: 915-921.

13.Ekor, M., Emerole, G.O. and Farombi, E.O. (2010). Phenolic extract of soybean (Glycine max) attenuates cisplatininduced nephrotoxicity in rats. Food Chem. Toxicol., 48: 1005-1012.(not cited in the text)

14.Fan, S.H., Zhang, Z.F., Zheng, Y.L., Lu, J., Wu, D.M., Shan, Q., Hu, B. and Wang, Y.Y. (2009). Troxerutin protects the mouse kidney from d-galactose-caused injury through anti-inflammation and anti-oxidation. Int. Immunopharmacol., 9: 91-96.

15.Farooqui, A.A. and Horrocks, L.A. (1998). Lipid peroxides in the free radical pathophysiology of brain diseases. Cell. Mol. Neurobiol., 18: 599-608.

16.Feng, L., Ke, N., Cheng, F., Guo, Y., Li, S., Li, Q. and Li, Y. (2011). The protective mechanism of ligustrazine against renal ischemia/reperfusion injury. J. Surg. Res., 166: 298-305.

17.Ghule, A.E., Jadhav, S.S. and Bodhankar, S.L. (2011). Renoprotective effect of Linum usitatissimum seeds through haemodynamic changes and conservation of antioxidant enzymes in renal ischaemia-reperfusion injury in rats. Arab J. Urol., 9: 215-221.

18.Halliwell, B. (1995). How to characterize an antioxidant: an update. Biochem. Soc. Symp., 61: 73-101.

19.Huang, W.Y., Cai, Y.Z., Corke, H. and Sun, M. (2010). Survey of antioxidant capacity and nutritional quality of selected edible and medicinal fruit plants in Hong Kong. J. Food Compos. Anal., 23: 510-517.

20.Keter, L.K. and Mutiso, P.C. (2012). Ethnobotanical studies of medicinal plants used by Traditonal Health Practitioners in the management of diabetes in Lower Eastern Province, Kenya. J. Ethnopharmacol., 139: 74-80.

21.Khan, M.R., Siddiqui, S., Parveen, K., Javed, S., Diwakar, S. and Siddiqui, W.A. (2010). Nephroprotective action of tocotrienol-rich fraction (TRF) from palm oil against potassium dichromate $\left(\mathrm{K}_{2} \mathrm{Cr}_{2} \mathrm{O}_{7}\right)$-induced acute renal injury in rats. Chem. Biol. Interact., 186: 228-238.

22.Marnewick, J.L., Rautenbach, F., Venter, I., Neethling, H., Blackhurst, D.M., Wolmarans, P. and Macharia, M. (2011). Effects of rooibos (Aspalathus linearis) on oxidative stress and biochemical parameters in adults at risk for cardiovascular disease. J. Ethnopharmacol., 133, 46-52.

23.Martins, S., Mussatto, S.I., Martínez-Avila, G., Montañez-Saenz, J., Aguilar, C.N. and Teixeira, J.A. (2011). Bioactive phenolic compounds: production and extraction by solid-state fermentation. A review. Biotechnol. Adv., 29: 365-373.

24.Mehta, R.L., Pascual, M.T., Soroko, S., Savage, B.R., Himmelfarb, J., Ikizler, T.A., Paganini, E.P., Chertow, G.M. (2004). Spectrum of acute renal failure in the intensive care unit: the PICARD experience. Kidney Int., 66: 1613-1621.

25.Mehta R.L., Kellum J.A., Shah S.V., Molitoris B.A., Ronco C., Warnock D.G., Levin A. (2007). Acute Kidney Injury Network: report of an initiative to improve outcomes in acute kidney injury. Crit. Care, 11: 1-8.

26.Mein, J.R., Dolnikowski, G.G., Ernst, H., Russell, R.M. and Wang, X.D. (2011). Enzymatic formation of apocarotenoids from the xanthophyll carotenoids lutein, zeaxanthin and $\beta$-cryptoxanthin by ferret carotene- $9^{\prime}, 10^{\prime}-$ monooxygenase. Arch. Biochem. Biophys., 506: 109-121.

27.Nash, K., Hafeez, A. and Hou, S. (2002). Hospital-acquired renal insufficiency. Am. J. Kidney Dis., 39: 930-936. 


\section{http://dx.doi.org/10.4314/ajtcam.v10i4.15}

28.Olaleye, M.T. and Rocha, B.T. (2008). Acetaminophen-induced liver damage in mice: effects of some medicinal plants on the oxidative defense system. Exp. Toxicol. Pathol., 59: 319-327.

29.Palace, V.P., Khaper, N., Qin, Q. and Singal, P.K. (1999). Antioxidant potentials of vitamin A and carotenoids and their relevance to heart disease. Free Radic. Biol. Med., 26: 746-61.

30.Palipoch, S., Jiraungkoorskul, W., Tansatit, T., Preyavichyapugdee, N., Jaikua, W. and Kosai, P. (2011a). Effect of Thunbergia laurifolia (Linn) Leaf Extract Dietary Supplement Against Lead Toxicity in Nile Tilapia (Oreochromis niloticus). World J. Fish Marine Sci., 3: 1-9.

31.Palipoch, S., Jiraungkoorskul, W., Tansatit, T., Preyavichyapugdee, N., Jaikua, W. and Kosai, P. (2011b). Protective efficiency of Thunbergia laurifolia leaf extract against lead (II) nitrate-induced toxicity in Oreochromis niloticus. J. Med. Plants Res., 5: 719-728.

32.Pieper, G.M., Langenstroer, P. and Siebeneich, W. (1997). Diabetic-induced endothelial dysfunction in rat aorta: role of hydroxyl radicals. Cardiovasc. Res., 34: 145-156.

33.Qin, C.X., Williams, S.J. and Woodman, O.L. (2011). Antioxidant activity contributes to flavonol cardioprotection during reperfusion of rat hearts. Free Radic. Biol. Med., 51: 1437-1444.

34.Qin, F., Liu, Y.X., Zhao, H.W., Huang, X., Ren, P. and Zhu, Z.Y. (2009). Chinese medicinal formula Guan-Xin-Er-Hao protects the heart against oxidative stress induced by acute ischemic myocardial injury in rats. Phytomedicine, 16: 215221.

35.Rao, A.V. and Agarwal, S. (2000). Role of antioxidant lycopene in cancer and heart disease. J Am. Coll. Nutr., 19: 563569.

36.Rao, A.V. and Rao, L.G. (2007). Carotenoids and human health. Pharmacol. Res., 55: 207-216.

37.Reddy, S.S., Ramatholisamma, P., Karuna, R. and Saralakumari, D. (2009). Preventive effect of Tinospora cordifolia against high-fructose diet-induced insulin resistance and oxidative stress in male Wistar rats. Food Chem. Toxicol., 47: 2224-2229.

38.Reyes, L.F., Miller, J. and Cisneros-Zevallos, L. (2005). Antioxidant capacity, anthocyanins and total phenolics in purple-and red-fleshed potato (Solanum tuberosum L.) genotypes. Am. J. Potato Res., 82: 271-277.

39.Riley, P.A. (1994). Free radicals in biology: oxidative stress and the effects of ionizing radiation. Int. J. Radiat. Biol., 65 : 27-33.

40.Rogers, L.K., Bates, C.M., Welty, S.E. and Smith, C.V. (2006). Diquat induces renal proximal tubule injury in glutathione reductase-deficient mice. Toxicol. Appl. Pharmacol., 217: 289-298.

41.Roxborough, H.E., Mercer, C., McMaster, D., Maxwell, A.P. and Young, I.S. (1999). Plasma glutathione peroxidase activity is reduced in haemodialysis patients. Nephron., 81: 278-283.

42.Sailaja, R. and Setty, O.H. (2006). Protective effect of Phyllanthus fraternus against allyl alcohol-induced oxidative stress in liver mitochondria. J. Ethnopharmacol., 105: 201-219.

43.Salmon, A.B., Richardson, A. and Pérez, V.I. (2010). Update on the oxidative stress theory of aging: does oxidative stress play a role in aging or healthy aging? Free Radic. Biol. Med., 48: 642-655.

44.Sen, S., Chen, S., Feng, B., Wu, Y., Lui, E. and Chakrabarti, S. (2011). American ginseng (Panax quinquefolius) prevents glucose-induced oxidative stress and associated endothelial abnormalities. Phytomedicine, 18: 1110-1117.

45.Seok, Y.M., Kim, J., Choi, K.C., Yoon, C.H., Boo, Y.C., Park, Y. and Park, K.M. (2007). Wen-pi-tang-Hab-Wu-lingsan attenuates kidney ischemia/reperfusion injury in mice. A role for antioxidant enzymes and heat-shock proteins. J. Ethnopharmacol., 112: 333-340.

46.Sorg, O. (2004). Oxidative stress: a theoretical model or a biological reality? C. R. Biol., 327: 649-662.

47.Sroka, Z. and Cisowski, W. (2003). Hydrogen peroxide scavenging, antioxidant and anti-radical activity of some phenolic acids. Food Chem. Toxicol., 41: 753-758.

48.Sutton, T.A. (2009). Alteration of microvascular permeability in acute kidney injury. Microvasc. Res., 77: 4-7.

49.Valko, M., Leibfritz, D., Moncol, J., Cronin, M.T., Mazur, M. and Telser, J. (2007). Free radicals and antioxidants in normal physiological functions and human disease. Int. J. Biochem. Cell Biol., 39, 44-84.

50.Van Biesen, W., Vanholder, R. and Lameire, N. (2006). Defining acute renal failure: RIFLE and beyond. Clin. J. Am. Soc. Nephrol., 1: 1314-1319.

51.Young, I.S. and Woodside, J.V. (2001). Antioxidants in health and disease. J. Clin. Pathol., 54: 176-186.

52.Ziech, D., Franco, R., Georgakilas, A.G., Georgakila, S., Malamou-Mitsi, V., Schoneveld, O., Pappa, A. and Panayiotidis, M.I. (2010). The role of reactive oxygen species and oxidative stress in environmental carcinogenesis and biomarker development. Chem. Biol. Interact., 188: 334-339. 